\title{
El euskera en la novela Patria de Fernando Aramburu ${ }^{1}$
}

\section{The Basque Language in the Novel Patria by Fernando Aramburu}

\author{
Karlos Cid Abasolo \\ Universidad Complutense de Madrid \\ abasolo@ucm.es \\ Recibido: marzo de 2019. Aceptado: abril de 2019.
}

\begin{abstract}
Resumen: En este artículo se analiza la presencia de la lengua vasca en la novela Patria, de Fernando Aramburu, best seller del año 2016. Aramburu, como es sabido, escribe en español, pero en esta novela, al igual que en otras obras anteriores, introduce, por un lado, palabras o frases en euskera con una determinada intencionalidad, y, por otro, referencias y reflexiones (propias y, sobre todo, de los personajes) sobre la lengua vasca. Tanto las unas como las otras son el objeto de estudio de este trabajo.

En la parte final del artículo se incluye la corrección de errores del glosario que aparece al final de la novela, glosario (citamos textualmente) de «vocablos y modismos procedentes del euskera». En algunos casos, los errores se encuentran en la definición y, en otros casos, en el hecho de que algunas de las palabras no procedan del euskera.
\end{abstract}

Palabras clave: euskera - espacuence - verosimilitud lingüística - letra cursiva - glosario

\begin{abstract}
This article analyses the presence of the Basque language in the novel Patria, by Fernando Aramburu, best seller of the year 2016. Aramburu, as is well known, writes in Spanish, but in this novel, as in other previous works, he introduces, on the one hand, words or phrases in Basque with a certain intentionality, and on the other, references and reflections (of the author himself and, above all, of the characters) on the Basque language. Both are the object of study of this work. The final part of the article includes the
\end{abstract}

1 Agradezco al escritor Iban Zaldua el haber aportado a este trabajo sugerentes observaciones que han servido para depurarlo y enriquecerlo. 
correction of errors in the glossary at the end of the novel, a glossary (we quote verbatim) of «words and idioms derived from the Basque language». In some cases, errors lie in the definition, and in others, in the fact that some of the words do not come from the Basque language.

Keywords: Basque - spabasque - linguistic verisimilitude - italics - glossary

\section{I.- INTRODUCCIÓN}

Para el personal docente e investigador de las Facultades de Filología, parece de obligado cumplimiento dedicarse, o bien a cuestiones literarias, o bien a cuestiones lingüísticas, mostrando entusiasmo por las unas y cierto o total desdén hacia las otras. Sin embargo, en nuestra opinión, existe una tercera vía: la de establecer puentes entre Literatura y Lingüística, la de analizar aspectos lingüísticos en obras literarias. Eso es precisamente lo que hicimos en algunos trabajos anteriores, partiendo de la narrativa de Anjel Lertxundi y Bernardo Atxaga ${ }^{2}$. Y eso es precisamente lo que vamos a hacer ahora, dada la relevancia de las cuestiones lingüísticas en la concepción de la novela Patria, de Fernando Aramburu, publicada en 2016³. En Patria, la lengua (la lengua vasca, el euskera, el vasco, el

2 Véase Cid Abasolo (2008, 2009, 2015, 2018).

3 Consideramos de gran utilidad reproducir aquí algunos pasajes de la crítica que hizo Iban Zaldua (22/03/2017) a dicha novela, en concreto, aquellos dedicados a aspectos lingüísticos, pues pueden servir de introducción de ideas que iremos desgranando a lo largo de este artículo: «(...) Aunque yo diría que eso no es lo peor en relación al lenguaje de Patria. Se supone que ambas familias son vascoparlantes y que, por lo tanto, se comunican principalmente en euskera (aunque eso se hace explícito muy pocas veces a lo largo de la novela, algo extraño, porque en una sociedad diglósica como la vasca es una de las cuestiones que el escritor tiene que abordar si quiere dotar de verosimilitud a sus novelas; los escritores en euskera no suelen perder de vista este problema y han encontrado diversas vías para solucionarlo o para soslayarlo, como hace Ramon Saizarbitoria, por poner un ejemplo, en Martutene o La educación de Lili). Sin embargo, en muchas ocasiones, la «supuesta» traducción al español de las palabras de los personajes aparece plagada de vasquismos, sobre todo del uso del condicional en lugar del subjuntivo («si tendría»...), tan común (por lo visto) en el castellano del norte de España. Un defecto que no debería aparecer si realmente estuvieran hablando en euskera (se entiende que correctamente) en la hipotética Urversión de las conversaciones de la novela. Y, lo que es peor, aunque, como he señalado, todos los miembros de ambas familias son euskaldunes, resulta que, según nos alejamos del epicentro terrorista-abertzale de la novela (formado por Miren y su hijo Joxe Mari, y, por extensión, Joxian), el castellano de los personajes va mejorando notablemente. Es decir, la lengua se utiliza como marcador moral (Aramburu ya lo hacía en algún cuento de Los peces de la amargura, como el titulado «Maritxu»), algo que quizá pase desapercibido para el lector no bilingüe, pero que para mí resta, una vez más, verosimilitud a la novela (Por cierto, ¿cómo se reflejará este rasgo en las traducciones al inglés o al alemán? Reconozco que es una cuestión que me intriga. Bueno, me intriga un poquito, tampoco quiero exagerar). Son, seguramente, las desventajas de no ser un escritor bilingüe, o, al menos, de no tener un conocimiento básico de la otra lengua oficial de su comunidad: alguien que sepa, además de castellano, euskera, jamás haría concebir a una vascoparlante como Nerea (al intentar aprender alemán) un pensamiento como este: No le entraba en la cabeza que a estas alturas de la Historia la gente, en la panadería, en el hospital, de ventana 
vascuence o como queramos llamarla) es un tema central, una suerte de obsesión para el novelista donostiarra y para no pocos de sus personajes.

Patria nos cuenta la historia de dos familias que viven en un pueblo de Guipúzcoa cuyo nombre es deliberadamente omitido por el autor («Como cuando Gorka volvió un sábado de su pueblo, al que había ido de víspera», p. 467), a diferencia de otras poblaciones guipuzcoanas (Orio, Azpeitia, etc.), que sí son explicitadas. Una de las familias está formada por Bittori y el Txato (apodo que esconde una identidad nunca revelada en las 642 páginas del libro), y sus hijos Xabier y Nerea. La otra, por Miren y Joxian, y sus hijos Arantxa, Joxe Mari y Gorka. Los dos matrimonios mantienen una gran amistad hasta que esta se rompe cuando el Txato es amenazado por ETA. Posteriormente, el Txato es asesinado, atentado en el que está implicado Joxe Mari, que previamente se había incorporado a ETA.

\section{II.- INVEROSIMILITUD LINGÜÍSTICA}

¿En qué lengua está escrita Patria? Nadie duda en incluirla en la narrativa en lengua castellana. Sin embargo, no todo lo que está escrito en Patria es castellano. La opción lingüística adoptada por el autor es, precisamente, uno de los objetos de estudio fundamentales de este artículo. Como decíamos, no todo en Patria es castellano: a través de las 642 páginas encontramos numerosas expresiones euskéricas, razón por la cual Aramburu decidió añadir un glosario al final de la novela. En el último apartado de este artículo analizaremos dicho glosario ya que, sorprendentemente, en él se alternan glosas correctas con no pocas incorrectas o incompletas, que hemos rehecho.

Aramburu, al comienzo de una de las presentaciones del libro en Madrid ${ }^{4}$, afirmó que, en la novela, «el uso de palabras en euskera está muy dosificado», relacionando tal decisión con el hecho de no incluir dedicatoria, prólogo y notas al pie de página y pretextando para todo ello lo siguiente: «No he querido intervenir desde fuera del texto para nada».

El autor, con esa declaración de intenciones, intenta justificar una decisión que, a nuestro juicio y en opinión de Iban Zaldua (2017), no funciona desde el punto de vista de la verosimilitud: Aramburu sitúa la mayor parte de la acción en una comarca vascohablante, los personajes son vascohablantes (por ejemplo,

a ventana, se expresara con declinaciones, a la usanza de los antiguos romanos. $\mathrm{O}$ de los actuales euskaldunes, añadiría yo...».

413 de septiembre de 2016. Compartió mesa con él el periodista Iñaki Gabilondo, que dos años antes había hecho lo propio con Ramon Saizarbitoria en la presentación, en el Círculo de Bellas Artes de Madrid, de la traducción al español de la novela de este, Martutene. Asimismo, meses después de la presentación del libro de Aramburu, los dos escritores guipuzcoanos mantuvieron un coloquio en la librería Lagun de San Sebastián, acto al que nos referiremos más adelante. 
los miembros de las dos familias protagonistas $)^{5}$, pero, en la novela, entre ellos ${ }^{6}$ se relacionan en espacuence, es decir, en ese castellano del País Vasco trufado de palabras vascas, palabras-barniz ${ }^{7}$. Con el recurso del espacuence, Aramburu quiere tener la deferencia con el lector no vascohablante (es decir, el tipo de lector mayoritario de la novela) de traducirle los diálogos, pero manteniendo un barniz, un resto de la lengua original de los mismos.

Entre las dos es más fácil sacar a Arantxa de la cama. Miren se reserva el tronco y la cabeza. Primero, eso sí, al tiempo que levanta la persiana, dispensa a su hija unas muestras matinales de ternura en euskera: egun on, polita y así (p. 75).

El problema es que Aramburu no los traduce al español estándar, sino al espacuence. Y es una decisión fallida porque el espacuence es una variante lingüística existente, por cierto, la mayoritaria de la Comunidad Autónoma Vasca (en adelante, CAV), como puede observarse no solo en sus ciudades y pueblos, sino también en numerosos medios de comunicación tales como algunos periódicos (Deia, Gara), la cadena de televisión pública ETB2, o la emisora pública Radio Euskadi. Para quien conozca la idiosincrasia lingüística de dicho territorio, que los personajes se expresen en la novela en espacuence no crea el efecto de que esos diálogos, en realidad, han tenido lugar en euskera. El resultado desconcierta a este tipo de lector porque hay en la novela otros diálogos en espacuence en los que no hay «traducción» del euskera al espacuence: por ejemplo, diálogo entre dos no vascohablantes; o entre un vascohablante y un no vascohablante; o entre vascohablantes que optan por el espacuence en lugar del euskera, algo que no resulta nada infrecuente. Pero, como decimos, esas dos posibilidades (euskera «traducido» al espacuence, o espacuence en «versión original») confluyen en la novela en una sola, de modo que el lector no sabe en qué idioma se sustancian realmente muchos de los diálogos.

Kaixo el uno; un kaixo tímido, soso, ellos dos. Y la entrevista transcurrió desde el primer momento por buen cauce (...).

-Tú entonces eres el hijo del carnicero (p. 276).

A este respecto, es preciso analizar las estrategias respecto al uso del espacuence que han utilizado los traductores de Patria a otras lenguas. ¿Diálogos en polaco, neerlandés, francés, inglés, italiano, etc. con expresiones euskéricas intercaladas de espacuence, y glosario al final del libro, en consonancia con

${ }^{5}$ Su condición de vascohablantes queda clara en numerosos momentos de la novela ( «Los dos matrimonios callejeaban con todas sus criaturas. Se habían reído con los bertsolaris», p. 112).

${ }^{6}$ O, por ejemplo, cuando hablan con San Ignacio de Loyola. Miren, en cierta ocasión, le pregunta al santo: «¿Con quién estás, con esos o con nosotros?» (p. 123). Es de suponer que, en realidad, se dirige a él en euskera y que en la novela se sustituye la versión original por la traducción al español.

7 Espacuence y palabras-barniz son neologismos que propusimos en un trabajo anterior (Cid Abasolo 2013). 
el modus operandi de Aramburu? ¿O renuncia al espacuence y, por tanto, al glosario? En el caso de la traducción al francés, de Claude Bleton, y al inglés, de Alfred Macadam, según hemos comprobado, el traductor mantiene el espacuen$c e$ del texto original de Aramburu y, al final de la novela, el glosario. Es decir, Bleton y Macadam han optado por la primera de las dos estrategias. Y, de inmediato, nos surge la siguiente pregunta: ¿Qué percepción puede tener el lector francófono a anglófono de ese francuence o inglescuence, es decir, del hecho de que los personajes vascos euskaldunes se expresen en francés o inglés, pero intercalando en ocasiones algunas expresiones en euskera?

Obviamente, en su decisión lingüística, Aramburu ha pensado en el lector mayoritario y en la editorial (seguramente complacidos de la «dosificación en el uso de palabras en euskera» y de la ausencia de notas a pie de página), anteponiéndolos a la verosimilitud lingüística. Si en Patria, en aras de un realismo que encontramos, por ejemplo, en novelas y películas donde se emplea más de una lengua, hubieran estado escritos en euskera los diálogos que en la «versión original» tienen lugar en euskera, Aramburu habría tenido que recurrir a las notas a pie de página, recurso rechazado por muchos novelistas y editoriales. Habría resultado realista, sí, pero acaso poco atractivo para el lector medio. Por otro lado, desconocemos si Aramburu sabe euskera: en caso negativo y de haber querido respetar la verosimilitud lingüística, habría tenido que recurrir a un traductor y, por tanto, habría perdido el control de parte de su texto.

En definitiva, el espacuence no sirve para dar la impresión de que un diálogo tiene lugar en euskera, por lo que la opción lingüística de Aramburu resulta fallida por equívoca, como cuando nos dice «Arantxa, agresiva, desafiante, se arrancó a hablar en castellano» (p. 437), cuando el diálogo previo está escrito en español sin que se le hubiera informado al lector de que, en realidad, se estaba hablando en euskera.

Si bien, como decimos, no hay ni un diálogo en euskera, ni una sola frase en vasco en los diálogos (diálogos y frases originalmente en euskera «se traducen» al espacuence), en cambio, Aramburu no «traduce» frases euskéricas relacionadas con la violencia y el terrorismo, sino que mantiene la «versión original», como ocurre con pintadas ( «TXATO ENTZUN PIM PAM PUM», p. 35) y otras proclamas («Alde hemendik», p. 116; «Herriak ez du barkatuko», p. 159; «Presoak kalera, amnistia osoa», p. 167; «Gora ETA!», p. 169). Las pintadas amenazadoras, los eslóganes, los grafitis en los calabozos de la Dirección General de la Guardia Civil en Madrid ${ }^{8}$, etc. en euskera están siempre escritos en euskera en la novela, de manera que aquí Aramburu sí los diferencia de los emitidos en castellano, mucho menos frecuentes ( «Vosotros, fascistas, sois los terroristas», p.70). A veces, en algunas de estas proclamas existe alternancia de código («Txato faxista, opresor, ETA mátalo», p. 212; «Policía asesina; Txakurrak kanpora», p. 300). Así pues, en los panfletos y amenazas Aramburu sí apuesta por el realismo lingüístico. La ausencia de este en unos casos y su pre-

8 «Y en la pared, sorpresa, había frases escritas en euskera, y el anagrama de ETA, y un contorno de Euskal Herria alrededor del lema: Gora Euskadi askatuta» (p. 510). 
sencia en otros crean o pueden crear en la mente del lector una vinculación entre el euskera y la violencia.

Nótese, además, que Aramburu no tiene inconveniente en introducir alguna frase en inglés en los diálogos, algo que, insistimos, no hace ni una sola vez en euskera.

Por primera y única vez la chica se dirigió a Nerea. En inglés.

-He's my boyfriend. And who are you?

Para entonces Nerea había captado todo el sentido de la situación. Habló primero a la chica, con marcada pronunciación, sin perder la calma:

-I thought he was my boyfriend (pp. 399-400).

En nuestra opinión, si la novela estuviera escrita en euskera o en bilingüe (con los diálogos en «versión original», ya en euskera, ya en español), no se crearía ese efecto, ya mencionado, de vinculación del euskera con la violencia y el terrorismo que en Patria se transmite al lector. Efecto que se produce también en las traducciones de la novela al mantenerse las palabras vascas dentro de un texto escrito en francés, inglés, etc. Efecto, en suma, que no se habría producido ni en el texto original ni en las traducciones si el lector hubiera visto expresarse en euskera a personajes como Bittori, Gorka, Xabier, Nerea o Arantxa, opuestos a ETA y su entorno.

La falta de verosimilitud lingüística salvo en proclamas políticas y apologías de la violencia es la misma que encontramos, por ejemplo, en la película Ocho apellidos vascos (2014), dirigida por Emilio Martínez Lázaro: personajes vascohablantes que entre ellos jamás hablan en euskera (siempre en espacuence) y, por el contario, manifestantes que gritan consignas en euskera. La irrealidad lingüístico-literaria (en el caso de Patria) y la lingüístico-cinematográfica (en el caso de Ocho apellidos vascos) se oponen a la realidad (en perjuicio del euskera y, sobre todo, de la imagen que se transmite de los vascohablantes), lo que, dicho sea de paso, no ha impedido el éxito de la película y de la novela en el País Vasco.

Solo en casos contados, Aramburu precisa que una intervención de algún personaje va a ser en euskera.

Él (Don Serapio) dijo (a Bittori) en euskera que la venía a visitar (p. 118).

Los saludó, seco, en euskera (p. 271).

(Don Serapio) se expresaba parsimonioso, en un euskera pulcro de seminario, salpicado de modismos añejos (p. 348).

Joxe Mari y Miren dialogaban siempre en euskera, enigmáticos según en qué temas, con abundancia de sobreentendidos, por si graban (p. 620).

Y si dicha intervención la quiere incorporar al texto, lo hace, tal como ya hemos indicado, en su «traducción» al castellano/espacuence. 
Y Joxe Mari, en el locutorio de la cárcel, susurrando en euskera, confirmó la historia:

-A mí me han dicho que llevaba una temporada raro (p.229).

Otra sorprendente falta de verosimilitud lingüística, la cual pasa desapercibida para el lector carente de información sobre la lengua vasca, consiste en que en la novela se diga que Nerea, vascohablante, tiene dificultades para aprender alemán por el hecho de ser una lengua con declinaciones.

Difícil idioma. No le entraba en la cabeza que a estas alturas de la Historia la gente, en la panadería, en el hospital, de ventana a ventana, se expresara con declinaciones, a la usanza de los antiguos romanos (p. 327).

Sorprendente, sí, teniendo en cuenta que el euskera, lengua nativa de Nerea, también se declina. Zaldua (2017) intenta justificar, si bien con un cauteloso «seguramente», a Aramburu («Son, seguramente, las desventajas de no ser un escritor bilingüe, $o$, al menos, de no tener un conocimiento básico de la otra lengua oficial de su comunidad»), cuando resulta imposible que Aramburu, donostiarra, hombre culto, y licenciado en Filología Hispánica (es decir, con formación lingüística) desconozca que el euskera se decline, de modo que solo cabe pensar que ha incurrido deliberadamente en esta falta de verosimilitud. A Nerea, claro está, le puede resultar difícil aprender alemán, pero no por el hecho de que esta sea una lengua con declinación.

Hemos detectado otro caso de inverosimilitud lingüística en un pasaje referido al periodo en que Joxe Mari, ya integrado en ETA, permanece oculto en una casa del País Vasco francés: «Tuvo una disputa en euskera, pues él no hablaba ni jota de francés, con la dueña de la casa por causa de la comida» (p. 385). Llama la atención que, a ojos de Aramburu, un vascohablante español se comunique en euskera con una vascohablante francesa solo por el hecho de que él no sepa francés. Para Aramburu, si Joxe Mari hubiese sabido francés, lo lógico habría sido que se hubiese relacionado en dicha lengua con la mujer vascofrancesa, aunque ambos tengan el euskera como lengua materna y no hubieran tenido ningún problema en comunicarse en vasco: de hecho, el dialecto de él y el dialecto de ella son más parecidos entre sí que, por ejemplo, el de él y el dialecto vizcaíno.

\section{III.- CARACATERÍSTICAS DEL ESPACUENCE DE PATRIA}

El espacuence que encontramos en Patria coincide con la descripción que hacíamos de él en un trabajo anterior (Cid Abasolo 2013). Las palabras-barniz de Patria figuran en cursiva, al igual que en dos obras anteriores de Aramburu ambientadas en el País Vasco: Los peces de la amargura (2006) y Años lentos (2012). A continuación, ofrecemos una clasificación de las palabras-barniz que aparecen en Patria: 
a) Vocablos que expresan parentesco":

- aita («padre»). En espacuence, esa palabra, dicha en plural (aitas), no solo significa padre+padre, sino también madre+padre («Yo enseguida he llamado a los aitas», p. 240) por evidente influjo del español. En cambio, en euskera, la palabra que se usa como término englobador padre+madre o padres+madres no es aitak, sino gurasoak: es decir, en euskera se hace una diferenciación léxica similar a la que encontramos en inglés entre fathers y parents.

Aramburu pone en boca de Bittori, en lugar de un «tu aita», un «tu padre», en español, cuando, nada más haber sido asesinado su marido, se dirige a su hijo Xabier ( Porque yo quería levantar a tu padre», p. 371). En ese angustioso momento, Aramburu hace desaparecer el espacuence del cerebro de Bittori.

- ama «madre», a menudo, con sufijo con valor hipocorístico (amatxo «mamá», al igual que aitatxo «papá»).

- amona «abuela», en dialecto guipuzcoano.

- aitona «abuelo», en dialecto guipuzcoano.

- osaba «tío».

b) saludos: kaixo «hola», egun on «buenos días».

c) adjetivos empleados con función vocativa: polita «guapa» («Hasta mañana, polita», p. 28), maitia «cariño» («iQuieres que te traiga algo, maitia?», p. 571).

d) sustantivos relacionados con la violencia: txakurra «policía» (literalmente, «perro»), beltza (policía antidisturbios de la Ertzaintza, literalmente, «negro»), txakurrada «policía», en sentido colectivo (literalmente, «grupo de perros»), ekintza («acción terrorista», literalmente, «acción»), etc.

e) aranismos, es decir, palabras vascas inventadas en su día por Sabino Arana o sus colaboradores: lehendakari, Ertzaintza, ertzaina, abertzale, ikurriña, ikastola, etc. A diferencia de Aramburu, no las escribimos en cursiva por una razón que desvelaremos en el apartado IX.

f) topónimos: nos referimos aquí al espacuence que practica el propio Aramburu, cuando se refiere al «Pacto de Lizarra» en el siguiente pasaje: «Año tras año se agarraba a esperanzas (las próximas elecciones, el pacto de $\operatorname{Lizarra}^{10}(\ldots) »$, p. 625. Como bien sabe Aramburu, la expresión castellana correcta es «pacto de Estella», dado que Lizarra es el

9 En el espacuence se emplean unos nombres de parentesco (ama, aita, etc.) y otros no (alaba «hija», seme «hijo», etc.).

${ }_{10} \ll(\ldots)$ fue un acuerdo político suscrito el 12 de septiembre de 1998 en la localidad navarra de Estella (Lizarra en euskera) (...). Este pacto fue firmado por todos los partidos políticos vascos de carácter nacionalista, así como por Ezker Batua, Zutik, Batzarre y el Partido Carlista de Euskal 
topónimo vasco y Estella el correspondiente castellano de esa población navarra. Aramburu, mediante la expresión incorrecta «Pacto de Lizarra», repetida hasta la saciedad por gran cantidad de políticos y periodistas, está vinculando de forma consciente el euskera a una determinada ideología, es decir, está actuando como los personajes negativos de su novela.

El espacuence en Patria no solo se manifiesta en el léxico, sino también en la morfología y en la sintaxis:

- omisión del pronombre átono neutro con función de objeto directo («¿O todos sabéis y yo no?», p. 57; «Ya te hago», p. 419).

- repetición de adjetivo con valor enfático («robusto-robusto», p. 64).

- empleo del artículo determinado en lugar del adjetivo posesivo acompañando a nombres de parentesco ( $\ll$ Si el aita levantara la cabeza...», p. 13, en lugar de «Si tu padre levantara la cabeza...»; «Se acordó, agradecida, del aita», p. 402, en lugar de «Se acordó, agradecida, de su padre»; «La hija ya está en Londres», p. 23, en lugar de «Nuestra hija ya está en Londres»).

Si Aramburu hubiera sido coherente con el uso ortipográfico de la cursiva (ver apartado IX), todas las características del espacuence tendrían que haber figurado con letra cursiva, y ello ha ocurrido con el léxico, pero no con las de índole morfo-sintáctica que acabamos de mencionar.

Sorprende, por otro lado, que en el castellano que hablan los personajes esté ausente el leísmo en pronombres átonos femeninos con función de complemento directo (la > le, las > les), típico del castellano del País Vasco ${ }^{11}$. Dicho fenómeno no ha de entenderse como vasquismo, ya que el euskera carece de dichos pronombres.

Algunos personajes emplean el condicional en lugar de imperfecto de subjuntivo («Aunque sería mi aita, cagüendiós» p. 171; «Y de hierro, para que duraría muchos años», p. 174), rasgo característico, no solo del castellano del País Vasco, sino también del de otros territorios (por ejemplo, del hablado en la provincia de Burgos), y cuya condición de vasquismo es discutible. Como apunta Zaldua (2017), este rasgo lingüístico, que Aramburu, al igual que en Los peces de la amargura y en Años lentos, expresa en Patria siempre con letra cursiva, es una «marca moral» (se lo atribuye a los personajes abertzales de su novela, pero no a los que no lo son), y «no debería aparecer si realmente estu-

Herria, y distintos sindicatos y asociaciones, para buscar un proceso de diálogo y negociación que lograra el cese del terrorismo de ETA» (Wikipedia).

11 «-Joé, ama. Van mis amigas. ¿Qué pensarán de mí si, después de haberlo planeado todo las llamo para decirles que las dejo plantadas?», (p. 255); «Pero otro día que la vi en la calle, la paré (...)», (p. 264). 
vieran hablando en euskera (se entiende que correctamente) en la hipotética Ur-versión de las conversaciones de la novela».

\section{ALTERNANCIA DE CÓDIGO (CODE-SWITCHING) EN PATRIA}

La alternancia de código, habitual en comunidades bilingües de todo el mundo, es una constante entre los vascohablantes cuando se expresan en euskera (Cid Abasolo, 2014): suelen intercalar sintagmas y oraciones en otra lengua, a saber, en español o en francés, según sea una u otra la lengua de contacto. En el caso de Patria, hemos detectado solo dos ejemplos de alternancia de código.

El primero es la referencia a una conversación entre Bittori y Miren en la época en que eran grandes amigas: «Decían San Sebastián como decían Donostia. No eran estrictas. ¿San Sebastián? Pues San Sebastián. ¿Donostia? Pues Donostia. Se arrancaban a conversar en euskera, pasaban al castellano, vuelta al euskera y así toda la tarde» (p. 67). En este pasaje hay dos aspectos que nos llaman la atención: por un lado, la expresión «no eran estrictas» (no conocemos vascohablantes que lo sean en el sentido en que Aramburu la emplea); por otro lado, resulta inverosímil que Bittori y Miren digan «Donostia», dado que la forma que se utiliza en dialecto guipuzcoano es «Donosti», frente a la forma «Donostia», que corresponde al euskera estándar (euskera batúa).

El segundo ejemplo, ya citado anteriormente, es el siguiente: «Arantxa, agresiva, desafiante, se arrancó a hablar en castellano» (p. 437). Gracias a la indicación del cambio de código, el lector descubre que las frases previas que cruzan Miren y su hija, aunque Aramburu las pone en español, habían sido emitidas, en su «versión original», en euskera. Por otro lado, la razón del cambio de código la encontramos en los dos adjetivos que aporta Aramburu, a saber, «agresiva» $\mathrm{y}$ «desafiante». El cambio de código puede deberse a múltiples factores, siendo uno de ellos el estado de ánimo (alegría, enfado, etc.), que en su día nosotros analizamos a partir de un caso real ${ }^{12}$.

Aramburu, en los dos ejemplos mencionados, nos indica explícitamente que ha habido cambio de código, pero sin que ello se concrete en el propio diálogo. En cambio, en otra parte de la novela, Nerea se despide del trabajo haciendo alternancia de código español-inglés, sí recogida por Aramburu («Lo siento, amiguitos, but it's too late», p. 475). Lo que en Patria vale para el inglés no vale para el euskera.

\section{V.- VISIÓN QUE TIENEN LOS PERSONAJES SOBRE EL EUSKERA}

El vascuence es, como estamos viendo, uno de los núcleos temáticos fundamentales de la novela. Y lo demuestra, además, el hecho de que muchos de los personajes hagan referencias, en algunos casos de forma reiterada, a la lengua

12 Se trata de unas declaraciones del entrenador de remeros José Luis Korta en un programa de radio (Cid Abasolo 2014: 260-261). 
vasca, lo cual acaba o puede acabar condicionando la visión del lector sobre esta. En otras ocasiones, la visión de los personajes sobre el euskera no nos llega directamente a través de lo que ellos dicen, sino a través de los ojos y las palabras de otros personajes, de personas interpuestas. A continuación, desgranaremos dichas visiones:

\section{DON SERAPIO}

Este cura representa en Patria a amplios sectores de la iglesia vasca de otro tiempo, claramente posicionados a favor del nacionalismo vasco y próximos a ETA. En un momento de la novela, Don Serapio consuela a Miren diciendo que Joxe Mari lucha por el pueblo vasco. Y en su alocución incluye el euskera, vinculándolo al catolicismo, tal como había hecho en su momento Sabino Arana.

Por eso me atrevería a afirmar que sobre nosotros recae la misión cristiana de defender nuestra identidad, por tanto nuestra cultura y, por encima de todo, nuestra lengua. Si esta desaparece, dime, Miren, dímelo con franqueza, ¿quién rezará a Dios en euskera? ¿Te respondo yo? Nadie (p. 313).

La visión ideologizada que tiene Don Serapio del euskera es similar a la que, en una obra anterior de Aramburu, Años lentos, había mostrado otro cura: Don Victoriano.

Especial ahínco ponía en inducir a los chavales el aprendizaje del idioma vasco, persuadido de que este se moría sin remedio. Como usted recordará, por aquellos años, en el barrio de Ibaeta, no lo hablaban con soltura sino diez o doce entre ciento, y aun esos no más allá de la puerta de sus casas.

Mi primo Julen, la espalda recostada en la cabecera de la cama, repetía algunas noches para mí, con una voz que no parecía la suya, las prédicas clandestinas del cura.

-Don Victoriano dice: vasco es el que habla euskera. Los demás son medio vascos o directamente coreanos (...) (p. 48).

Zaldua (2017) ve en don Serapio uno de los ejemplos, si no de anacronismo, si al menos de «un cierto décalage temporal» que salpican la novela. En cambio, don Victoriano, personaje de algunas décadas antes, sí se ajusta al perfil de cura vasco de su época ${ }^{13}$. Es un personaje estereotipado pero acorde

13 «La presencia obsesiva de la religión y el papel dominante del cura don Serapio parecen más cosa de los años sesenta y setenta que de los ochenta o los noventa, por ejemplo, en los que el proceso de secularización del nacionalismo vasco (sobre todo del de izquierdas) estaba ya muy avanzado. Ese detalle le funciona mucho mejor a Aramburu en su novela Años lentos, ambientada precisamente en la época anterior a la que se sitúa esta; se nota que el autor la vivió de primera mano, y por eso pienso que su poder evocador chirría menos en aquella novela; en cambio, en Patria los discursos de Don Serapio a favor de ETA o de la literatura en euskera resultan inverosímiles, por extemporáneos o por burdos (cfr. pgs. 300-301 y 335)» (Zaldua 2017). 
con su tiempo; por el contrario, don Serapio es un personaje estereotipado anacrónico.

\section{MIREN}

Mezcla el racismo de corte aranista con la cuestión lingüística en numerosos pasajes de la novela, en particular, al mostrar su rechazo por su yerno. Su actitud y la del cura pueden despertar en el lector un sentimiento de antipatía hacia la lengua vasca.

Hala, si te crees tan listo, vete a contarle a don Serapio que tu hija se ha casado fuera de la iglesia con uno que no habla euskera (p. 342) ${ }^{14}$.

-¿Por qué nunca llamas a Guillermo por su nombre? ¿Te quema la palabra? Para ti supongo que él es un opresor...

-Muy vasco no es.

-Aquí nació, antes que yo...

-Hernández Carrizo y no habla euskera. Si eso es ser vasco... (p. 438).

Miren también insiste en esa misma dirección cuando va a la cárcel con su marido en el coche de Alfonso y Catalina, que tienen también allí a su hijo preso.

No se puede decir que ambos matrimonios estuvieran unidos por una estrecha amistad. Miren los criticaba a escondidas, principalmente por no hablar euskera. A Joxian le da igual cómo hablen. Así y todo, tampoco les tenía simpatía. ¿Por qué? Se encogía de hombros: ni idea. (p. 561).

Aramburu califica la actitud de Miren respecto a su lengua («el idioma de la patria» ${ }^{15}$ ) como «obsesión», una actitud muy distinta a la de su hija, a la de sus nietos y, sobre todo, a la de Guillermo, su yerno, que contraataca por la vía del humor irónico, del cual carece Miren.

Y su obsesión por el euskera. Esa actitud reivindicativa, exigente, que la llevaba a poner a prueba a sus nietos cada vez que la visitaban. Les hacía preguntas para inducirlos a hablar el idioma de la patria y ellos lo hablaban con naturalidad y soltura, aunque con las limitaciones propias de su corta edad. Y no era raro que si Guillermo se hallaba presente, los niños se pasaran sin darse cuenta al castellano.

Miren intervenía cortante, rigurosa:

${ }^{14}$ Es una declaración a través de la cual Aramburu deja clara la responsabilidad del cura en esa mentalidad.

15 El euskera es «el idioma de la patria», tanto para Miren (en un sentido) como para Guillermo y Aramburu (en el sentido opuesto). 
-Aquí hablamos euskera.

Lo cual era una forma de hacerle a Guillermo el vacío. A menudo hablaba con él por mediación de Arantxa.

-Pregúntale a tu marido si quiere más garbanzos. ${ }^{16}$

Y Arantxa, qué remedio, se volvía hacia Guillermo y le traducía la pregunta. Guillermo no perdía el sentido de humor.

-Dile que me ponga dieciocho unidades (pp. 434-435).

En una ocasión, descubrimos la manipulación que hace Miren del euskera. Y lo hacemos, no a través de ella misma, sino de su hija Arantxa, cuando lanza a su madre el siguiente reproche:

A tu hijo, del que estás tan orgullosa, le probaron delitos de sangre. Por eso está en la cárcel, por terrorista. Te lo repito, por terrorista, no por hablar euskera como le contaste a Endika. Mentirosa, más que mentirosa (pp. 437-438).

Al final de la novela, el personaje de Miren empieza a recular en su cerrazón. Así lo percibimos cuando se presenta de improviso, con su marido y su hija, en la boda de su hijo Gorka. Aun así, mantiene su insistencia en la cuestión lingüística, lo cual llega al lector, eso sí, con un tono más liviano («Y le faltó tiempo para tirarle a Ramuntxo una pregunta en euskera, con intención sin duda comprobatoria, que la conozco», p. 594). Ese nuevo tono es sustanciado mediante la expresión «que la conozco», la cual induce al lector a pensar que ese momento narrativo nos llega a través de los ojos y la voz de Joxian.

\section{EL TXATO}

Cuando es amenazado por ETA, el Txato quiere pensar que no le pasará nada malo, entre otras razones, por ser vascohablante («Los del pueblo me conocen. Soy de aquí, hablo euskera, no me meto en líos de política, doy trabajo», p. 150; «Soy más vasco que todos ellos juntos. Y lo saben. Hasta los cinco años yo no hablaba ni jota de castellano», p. 416; «Yo no puedo entender que unos tipos que pretenden defender el euskera maten a euskaldunes», p. 417). Ese mismo motivo también es esgrimido por Aránzazu, pareja de Xabier («¿Cómo van a hacer daño a tu padre, un vasco bueno y euskaldun?», p. 367). El euskera como salvoconducto ante la violencia es un lugar común en los personajes de Aramburu, como podemos comprobar en el relato «El hijo de todos los muertos», de Los peces de la amargura, obra publicada diez años antes que Patria.

${ }^{16}$ La decisión de Aramburu de traducir al castellano la «versión original en euskera» de los diálogos resulta aquí particularmente inadecuada. 
El aitá estaba amenazado. Yo, ni idea. Me enteré después, cuando ya lo habíamos enterrado. Le insistieron para que llevase escolta. No quiso. Hubo quien le aconsejó que abandonara por un tiempo el País Vasco. Dicen que respondió que él era de aquí y que de aquí no se movía. A cabezota no le ganaba nadie. (...). Hablaba euskera, tenía amigos nacionalistas..., seguramente no se imaginaba que alguien quisiera causarle daño (p. 194).

\section{BITTORI}

A diferencia de Miren, Bittori, también vascohablante, se coloca en una posición muy diferente respecto a la cuestión lingüística, algo que Aramburu plasma en contextos diversos, tales como las referencias a la toponimia ${ }^{17}$ y a las esquelas ${ }^{18}$.

Bittori, cuando quiere evidenciar su actitud de rechazo a Don Serapio, se dirige a él en castellano cuando es evidente que la lengua habitual entre ambos es el euskera. Y Aramburu utiliza el mismo adjetivo que empleará muchas páginas después para explicar la alternancia de código de Arantxa: «desafiante».

Él (Don Serapio) dijo (a Bittori) en euskera que la venía a visitar. Ella lo escrutaba con ostensible prevención, una mano en el canto de la puerta por si se terciaba cerrársela de golpe en las narices. Le respondió/ordenó, tuteadora, en castellano, que pasara (...).

-¿Haces vida aquí?

-Claro, es mi casa. (...).

(Don Serapio) prodigó halagos, ademanes de blanda amabilidad, palabras hinchadas de humilde entonación, tratando de gobernar el coloquio; pero ella, las pocas veces que intervino, tiró con desafiante resolución al castellano, de tal manera que don Serapio, en un claro gesto por quitar aspereza a la situación, desistió de emplear el euskera (p. 118).

En dicha escena encontramos la misma falta de verosimilitud lingüística a la que nos hemos referido anteriormente: primero leemos «¿Haces vida aquí?» y luego averiguamos que esa frase había sido pronunciada en euskera, pero Aramburu la había «traducido» al castellano para «dosificar» el uso de la lengua vasca en la novela.

17 «Nerea viajó a Arrasate (Bittori decía Mondragón) en marzo del 87», (p. 254). La toponimia es un elemento importante del espacuence (Cid Abasolo 2013: 271) y del vascuenzol (Cid Abasolo 2014).

18 Ante su próxima muerte, Bittori le dice a su hija Nerea: «Poned por favor dos esquelas en El Diario Vasco, una en castellano y otra en euskera» (p. 611). Las esquelas son, en la sociedad vasca de una generación muy concreta y a partir de una determinada edad, algo muy relevante. 


\section{JOXE MARI}

Tiene una visión similar a la de su madre, si no más acentuada. Establece un estrecho vínculo entre la consecución de la independencia para el País Vasco y la euskaldunización de toda la población, y lo expresa, también él, de forma «desafiante».

Joxe Mari bebió un trago de calimocho y, mirando desafiante a cada uno de la cuadrilla, les dijo que:

-Todo lo complicáis. A ver, si tenemos la independencia, lo demás ya lo arreglaremos entre nosotros. ¿Mejorar la vida de los trabajadores? Perfecto. Se mejora. ¿Quién lo va a impedir si nadie de fuera nos gobierna? El asunto del euskera. Pues lo mismo. Aquí aprende euskera todo cristo y no hay más que hablar (p. 172).

Ese punto de vista lo mantiene posteriormente en un consejo que da a su hermano Gorka («Tú dale duro al euskera, que también es parte de la lucha», p. 186) y en una carta que le escribe desde la cárcel a Bittori ( «Le escribió en un periquete, hostil, militante, rechazador. Nada, cuatro líneas. Que no se arrepentía; que aspiraba a una Euskal Herria independiente, socialista y euskaldun», p. 524).

Por otro lado, al igual que su madre, establece otro vínculo: entre el euskera y la pureza de sangre de origen foral, lo cual no resulta muy verosímil para su edad y la época en la que se sitúa el relato. Esta es la visión que tiene de Patxo, otro miembro de ETA: «No terminaba de congeniar con aquel chaval. Si es que, además, a Joxe Mari se le hacía raro estar todo el día pegado a alguien que no fuera de su pueblo. Patxo se había criado en Lasarte, no tenía apellidos vascos y no hablaba euskera. Este, ¿para qué se metía en la lucha?», p. 379.

El punto de vista de Joxe Mari llega también al lector a través de las palabras de su hermano Gorka. Es obvia la conexión con el punto de vista de su madre. Los comentarios del uno y de la otra son perfectamente intercambiables.

Gorka preguntó (a Arantxa) lo primero de todo cómo se llamaba el chico.

-Guillermo.

-Guillermo qué.

-Guillermo Hernández Carrizo.

Se incorporó en la cama, donde estaba leyendo.

-¿Es abertzale?

-No le interesa la política.

-Pero, por lo menos, habla euskera, ¿no?

-Ni una palabra. 
-Entonces, a Joxe Mari no le va a gustar (p. 208).

En la cárcel, la lengua vasca adquiere para Joxe Mari un valor nuevo: el de efecto balsámico. Hablar euskera y escuchar música en euskera le sirven de válvula de escape ${ }^{19}$. Por otro lado, desde la cárcel se cartea con Aintzane, una ondarresa que empieza a escribirle sin conocerlo, solo por el hecho de ser preso miembro de ETA. El cambio de lengua en la comunicación epistolar supone un cambio fundamental en la actitud lingüística de Joxe Mari: opta por escribir en castellano por puro pragmatismo.

Joxe Mari y Aintzane estuvieron comunicándose por carta un año largo antes de su primer encuentro. Al principio se escribían en euskera. Adoptaron el castellano al comprobar que de este modo se aceleraba el control de la correspondencia y a Joxe Mari le entregaban las cartas con mayor rapidez (p. 617).

\section{GORKA}

A través de este personaje y los más jóvenes de la novela ${ }^{20}$ (los hijos de Arantxa y la de Ramuntxo), encontramos las únicas visiones no negativas del euskera. Aramburu dice haber concebido a Gorka, en parte, como un álter ego, si bien se sitúa a sí mismo por encima de él ${ }^{21}$.

Aramburu alude una y otra vez al gran dominio del euskera del que hace gala Gorka («Su bien modulado euskera impresionaba y él lo sabía», p. 469; «A Ramuntxo, que le lleva once años, lo dejó anonadado el buen euskera que habla Gorka», p. 359), a diferencia del resto de vascohablantes mencionados en la novela. Aramburu dibuja un perfil ideológico de Gorka muy distinto del de otros que, siendo abertzales, no dominan el idioma como él, y de paso, aprovecha para lanzar una andanada a las ikastolas, considerándolas incapaces de alfabetizar adecuadamente en su propia lengua a alumnos vascohablantes.

El pequeño también aventajaba a Joxe Mari en el dominio del euskera. Leía con regularidad obras literarias de escritores euskaldunes y, desde los dieciséis años, escribía en dicho idioma poemas que sólo mostraba a Arantxa. Y, bueno, sin exagerar, les daba cien vueltas a Joxe Mari y a sus amigos, que hablaban lo que hablaban, o sea, el euskera de casa y de la calle ligeramente mejorado en la ikastola. Estos solían reunirse en sus respectivos domicilios para confec-

19 «Especialmente lo confortaban los ratos en que hablaba en euskera con algún compañero o en grupo. A veces entonaban canciones de la tierra, Izarren hautsa, algo de Lete, de Laboa, de Benito Lertxundi, sin alzar demasiado la voz para no provocar, o contaban chistes», p. 615.

${ }^{20}$ «Fernando Aramburu parece apuntar a que las generaciones más jóvenes empiezan a minimizar o ignorar las connotaciones políticas de sus opciones a la hora de utilizar uno u otro idioma» (Puente 2017).

${ }^{21}$ «Hay algo de mí en Gorka, el problema es que él no ha logrado cumplir su sueño, que es ser escritor, yo sí» (Sainz Borgo 2016). 
cionar carteles escritos a mano que luego pegaban en las paredes del pueblo. Alguna que otra vez Joxe Mari los convocaba en su habitación y allí Gorka les señalaba las faltas gramaticales y de ortografía que hubieran cometido, algunas de grueso calibre (pp. 185-186).

Todos conocían su afición a la lectura. Todos sabían que él no era de ir de juerga ni de salir por las noches. Lo normal es que se encerrara en casa o en la biblioteca municipal. Kartujo, le decían de burla. Pero en el fondo lo respetaban por su dominio del euskera (p. 251).

Asimismo, describe a Gorka como cosmopolita, deseoso de recorrer mundo, ampliar horizontes, a diferencia de la gente de su entorno.

A mí, de esta sumisión, sólo me sacarán un cambio de aires (Donostia, Bilbao, también fuera de Euskadi) y estudiar. Emprender estudios universitarios, su gran sueño. Filología Vasca, Psicología, en esa dirección. Cursar lo que sea en una universidad de París, de Londres, ¿te imaginas? (p. 252).

Aramburu hace deslizar en su novela la idea de que, salvo contadas excepciones como la de Gorka, una mayoría de vascohablantes hablan mal su lengua materna, prejuicio que no se sostiene desde un punto de vista estrictamente lingüístico pero sí ideológico, como sin duda sostendría el filólogo Juan Carlos Moreno Cabrera. Cuando Ramuntxo le da trabajo a Gorka en una emisora de Bilbao, con programación mayoritariamente en euskera, Aramburu aprovecha para insistir en el dominio de la lengua por parte de Gorka y en la impericia por parte, incluso, de los locutores de la emisora, dando así una vuelta de tuerca más a su visión lingüística, que trasmite al lector.

Y había locutores que maltrataban la gramática. Mejor para Gorka, quien, como leía de maravilla, se expresaba con fluidez, tenía un dominio enorme del idioma y, además, buena voz, en poco tiempo pasó de redactor, asistente, encargado de la discoteca, responsable de la cafetera y chico de los recados, a hablar ante el micrófono, al principio en compañía de Ramuntxo, más tarde solo (p. 360).

Por otro lado, cuando Ramuntxo le dice a Gorka que han asesinado a un empresario de su pueblo, Gorka descarta que este sea nacionalista y vascohablante, ya que, a gente de ese perfil, ETA podía exigirle el impuesto revolucionario, pero no matarla porque «en ese caso la banda tendría que vérselas con el PNV» (p. 459). Cuando averigua de quién se trata, se sorprende: «Era un hombre apolítico y también un hombre bueno, que daba trabajo a otros, muy de estar con la gente del pueblo y, por supuesto ${ }^{22}$, euskaldun», (p. 460).

Gorka se convierte especialmente en álter ego de Aramburu, más allá de lo podría suponérsele al propio personaje, cuando transmite a Ramuntxo (en otras palabras, cuando Aramburu le transmite al lector) una grave acusación contra

${ }^{22}$ El subrayado es nuestro. 
los escritores euskéricos, lo cual situamos aquí como un adelanto de lo que trataremos en el apartado VII de este artículo:

¿Te imaginas que tú y yo condenáramos mañana en la radio el asesinato de hoy? Antes del mediodía nos habrían cortado la subvención ${ }^{23}$ o nos pondrían de patitas en la calle. Con los libros pasa lo mismo. Como te salgas de la línea te conviertes en un apestado, incluso en un enemigo. El que escribe en castellano aún tiene salidas. Le publican en Madrid y Barcelona, y a lo mejor, con suerte y talento, sale adelante. No así los que escribimos en euskera. Te cierran las puertas, no te invitan a nada, no existes. Yo tengo claro que me pasaré la vida escribiendo para niños, aunque estoy hasta el gorro de brujas, dragones y piratas (pp. 462-463).

Gorka se pone como ejemplo, con su trabajo relacionado con el euskera, de quienes trabajan en favor del pueblo vasco, en oposición a los que dicen trabajar en favor de él mediante el uso de la violencia. En efecto, le dice a su hermano Joxe Mari cuando va a verlo a la cárcel:

Hago programas de radio en euskera, escribo libros en euskera, ayudo a nuestra cultura. Es mi manera de aportar algo a nuestro pueblo, pero algo constructivo, sin dejar a mi paso un montón de huérfanos y viudas (p. 582).

\section{JOSUNE}

Pareja de Joxe Mari y afín a este en lo ideológico. Sin embargo, Aramburu la sitúa en un nivel aún más radical que este respecto a la pureza de sangre y el tema lingüístico, colocándola en un nivel similar al de Miren. En la misma línea de lo que decíamos sobre Joxe Mari, dadas la edad que se le supone a Josune y la época en que ocurren los hechos novelados, no resulta muy verosímil en ella ese nacionalismo etnicista, reflejado, por ejemplo, en el uso de la palabra maqueto, más propio de otros tiempos.

A Joxe Mari tampoco le quitaba el sueño que Arantxa saliera con un chaval y lo trajera al pueblo a enseñarlo a los conocidos y a lo mejor a la familia.

-Es un maqueto. No hay más que verle la cara. Y no habla euskera.

${ }^{23}$ Ramón Zallo (2017) discrepa de lo que Aramburu pone en labios de Gorka. En opinión de Zallo, «esa foto es tan imposible como injusta. Falsa porque es inconcebible que Gobierno Vasco o la Diputación de Bizkaia (PNV) pudieran condicionar subvenciones a no denunciar a ETA cuando las propias instituciones lo hacían. Injusta, porque mayoritariamente el periodismo -en castellano o euskera- hilaba más grueso que fino frente a ETA también en la época y todos los días, fuera por convicciones o fuera porque les temían más a los dueños de los media, muy mayoritariamente decantados no solo contra ETA sino contra el nacionalismo. Es no conocer el país del que habla». El lector español, francés o polaco de Patria no tiene acceso a la visión de Zallo, quedándose solo con la de Aramburu. 
-¿Cómo lo sabes?

-Joder, porque cuando me lo ha presentado Arantxa le he hablado y el tío no se enteraba, y hemos tenido que seguir en castellano. Sería la de Dios que se os colara un español en la familia. Igual hasta es de la policía y con la excusa de salir con tu hermana se dedica a espiarnos a todos, empezando por ti.

A Joxe Mari se le arrugó el entrecejo.

-Que no hable euskera no quiere decir que...

-¿Qué? (p. 173).

El punto de vista de Josune nos llega también a través de persona interpuesta: Arantxa, cuando se dirige a su marido Guillermo en estos términos: "Ahí enfrente está una que sale con mi hermano. No te vuelvas. Ya vas a ver cómo se las arregla para averiguar quién eres y si hablas euskera» (p. 209).

\section{GUILLERMO}

La primera vez que el lector sabe de la (difícil) relación de Guillermo con el euskera es a través de las palabras de Arantxa ( $« \mathrm{El}$ pobre Guille. Pero si es un pedazo de pan. Se ha apuntado a clases de euskera, aunque lo veo crudo. Se me hace a mí que este hombre no vale para los idiomas», p. 264). La segunda vez, cuando se muda a su casa su cuñado Gorka y, entre otras contraprestaciones, se mencionan las clases particulares de euskera («Les ayudó a empapelar la sala. Les pintó él solo el techo de la cocina. Y, ya puestos a pagar un favor con otro, intentó enseñarle a su cuñado unos rudimentos de euskera. Lo tuvieron que dejar por imposible. Guille era un negado para los idiomas», p. 358). Así pues, Guillermo es incapaz de aprender euskera de la misma manera que sería incapaz de aprender cualquier otro idioma. Podríamos decir que no es algo personal. Pero sí lo es en la tercera ocasión, que supone la catarsis en esa difícil relación, ya no por la impericia de Guillermo en el aprendizaje de idiomas, sino por la sempiterna vinculación que, desde posiciones antagónicas, se ha establecido frecuentemente entre el euskera y una determinada ideología. Dicha catarsis se produce tras ser asesinados por ETA el concejal Manuel Zamarreño y, días después, dos guardias civiles. Guillermo estalla en casa, ante su mujer y sus hijos. La antroponimia vasca, los nombres de persona en euskera, salen a la palestra en ese preciso momento.

Endika, allí presente, haciendo los deberes del colegio, y Ainhoa en su cuarto, oyéndolo seguramente todo. Oyendo a su padre dar unas voces descomunales, monologar áspero, despotricar faltón y maldecir la hora en que había consentido en ponerles nombres vascos a sus hijos. Y ¿para qué? Para contentar a la abuela abertzale con la que ahora ni siquiera se hablaban» (p. 531). 


\section{JOKIN}

Coincide con su amigo Joxe Mari no solo en el plano ideológico, sino también en la visión sobre el euskera: «Al otro lado de la mesa, Jokin pintaba un panorama paradisíaco de socialismo e independencia, con los siete territorios de Euskal Herria unidos y sin clases sociales, donde hasta la hierba, cuánto te juegas, hablará euskera», p. 170. Los elementos enfáticos («donde hasta la hierba, cuánto te juegas») son introducidos por Aramburu en el discurso para acentuar esa visión.

\section{JOXIAN}

Marido de Miren y padre de Arantxa, Joxe Mari y Gorka, Joxian es, aparentemente, un personaje con poco peso en la novela (aunque quizás ese poco peso le dé, precisamente, mucho peso), habla poco, pero hace un comentario en la línea ya mencionada de vasquidad racial y lingüística. Lo lanza sobre Herminio, padre de Koldo (correligionario de Joxe Mari en ETA y su delator). Le acusa, entre otras cosas, de tener un nivel de euskera que no supera el umbral de un mini-espacuence de apenas dos palabras.

Herminio, un asimilado, un emigrante andaluz que vino de joven al pueblo a matar el hambre; cazó a Manoli, una vasca de caserío, ingenua y grandota, y con eso ya se creía más vasco que Dios. ¿Euskera? Sí, kaixo, egun on y para de contar (p. 225).

\section{PATXO}

Este miembro de ETA, por no ser vascohablante, es reconvenido por algunos de sus correligionarios, los cuales establecen, como otros personajes citados en este artículo, una estrecha relación entre ser vasco y ser vascohablante, punto de vista basado en la mera ideología según el cual, para ser vasco, no basta con haber nacido en el País Vasco.

A Patxo le asignaron un puesto de trabajo en una granja avícola, propiedad de un matrimonio francés de convicciones nacionalistas. Con los dueños y sus hijos, y la ayuda de un manual, se aplicó al aprendizaje del euskera. ¿No lo hablaba? Pues no, salvo las veinte palabras que se te pegan quieras que no ${ }^{24}, \mathrm{y}$ por esa razón sus compañeros solían reconvenirle con severidad. Si no hablas euskera, no eres vasco, le decían, aunque formes parte de ETA. Él alegaba su compromiso por la independencia. Lo mandaban a la mierda. (p. 501).

${ }^{24}$ Hemos subrayado esta sugerente definición de espacuence. 


\section{AINHOA}

Ainhoa, hija de Arantxa y nieta de Miren, no tiene sobre el euskera la visión de su abuela o de su tío Joxe Mari. ¿Cuál es la suya? No la manifiesta abiertamente, pero sí hemos localizado un comentario bastante revelador durante el episodio en el que su madre sufre el ictus en Mallorca. Carme, enfermera que atiende a Arantxa, acoge a Ainhoa en su casa en tanto llega su familia del País Vasco. El marido de Carme es alemán. Y la percepción de Ainhoa sobre la situación lingüística de esa familia es la siguiente: «A los niños les hablaban él en alemán, ella en ese euskera que tienen en Mallorca», (p. 91). Para Ainhoa, el catalán es, pues, «ese euskera que tienen en Mallorca». Una definición muy reveladora.

\section{AMAIA}

Hija de Ramuntxo, pertenece a la generación de jóvenes vascos que, según parece querer decirnos Aramburu, «empiezan a minimizar o ignorar las connotaciones políticas de sus opciones a la hora de utilizar uno u otro idioma» (Puente 2017). En el pasaje donde Amaia muestra su manera de vivir su bilingüismo, hace gala de una coherencia absoluta con su forma de ser (propia de la edad) en general, basada en llevar la contraria en todo, también en la lengua ( «Le hablabas en euskera, te respondía en castellano; seguías la conversación en castellano, se pasaba al euskera», p. 465).

\section{VI.- PATRIA Y LA LITERATURA EUSKÉRICA}

En Patria, Aramburu transmite al lector una visión sobre los escritores en lengua vasca coincidente con la que ha manifestado en múltiples declaraciones ofrecidas a diversos medios de comunicación. Entre ellas, cabe destacar las que concedió al periódico El País en $2011^{25}$ en el marco de la feria del libro de Guadalajara (México). El titular muestra claramente en qué aspecto de la entrevista quiere poner el énfasis el entrevistador: «Los escritores vascos no son libres, están subvencionados». El momento central de la entrevista es aquel en el que, ante la pregunta siguiente: «Al recibir el premio ha dicho que los escritores vascos no son libres. ¿Por qué?», Aramburu responde:

No lo son porque están subvencionados, forman parte de la campaña de promoción del idioma. En el País vasco se mantiene la ficción de que existen lectores en euskera y por tanto es necesario el apoyo oficial. La subvención tiene un doble peligro: te permite ser escritor pero sabes que si te sales del camino te pierdes parte del pastel. A Bernardo Atxaga le tengo un gran afecto, es una excelente persona, pero ha tocado el tema de ETA de manera metafóri-

${ }^{25}$ https://elpais.com/cultura/2011/11/30/actualidad/1322607602_850215.html. El País, 30 de noviembre de 2011. 
ca, sin nombrar lo evidente: el sufrimiento y la sangre. No es un hombre libre y trata de complacer a unos y a otros.

La entrevista levantó una gran polvareda en la cultura vasca y fuera de ella. Cinco días después, Aramburu publicó en ese mismo medio una carta de relativa rectificación ${ }^{26}$. Ello no evitó que al poco tiempo llegara la réplica de Anjel Lertxundi ${ }^{27}$, que negó la imagen que Aramburu difunde aquí y allá de los escritores euskéricos.

Las imaginarias prebendas que injustamente nos atribuye se convierten, siempre según sus primeras manifestaciones, en cadenas que nos privan de libertad y nos impiden hablar de ETA.

La cuestión es que, cuando habla Lertxundi, el altavoz tiene mucho menos alcance que cuando habla Aramburu. La lucha dialéctica es desigual a favor de Aramburu en cuanto al número de decibelios.

En dicho artículo de opinión, Lertxundi menciona «Isiltasuna ez da aterpe» («El silencio no es cobijo»), manifiesto contra ETA que en el año 2000 firmaron más de cien escritores (Lertxundi incluido), traductores, críticos literarios y dinamizadores culturales de la lengua vasca. Lertxundi, frente a lo que afirma Aramburu, aclara que ha habido escritores euskéricos comprometidos contra ETA. En esa misma línea, Iban Zaldua (2012, 2017), Edurne Portela (2016) y Mari Jose Olaziregi (2018) se han referido a las obras literarias en euskera que han tratado el tema de ETA (en muchos casos, desde una óptica abiertamente crítica para con la banda terrorista/la organización $\operatorname{armada}^{28}$ ), obras que parecen no existir para Aramburu.

Zaldua (2012: 75), por su parte, recoge unas declaraciones de Aramburu («En cuanto a la cuestión de la violencia política en el País Vasco, mi impresión personal es que a los escritores de la zona todavía les queda mucho por decir») y, como Lertxundi, le contradice, en los siguientes términos: «Aramburu no puede o, en todo caso, no suele leer lo que se escribe en euskera sobre la cuestión, y (...) quizá tampoco esté bien informado acerca de las traducciones al castellano disponibles en el mercado».

Ramon Saizarbitoria tuvo la oportunidad de reiterar ante el mismo Aramburu los argumentos de Lertxundi en un encuentro de ambos escritores en la librería Lagun de San Sebastián el 3 de noviembre de 2016, oficiando como moderador Ignacio Latierro. Aramburu aportó el dato (falso) de que los escritores en

26 «Carta a los escritores vascos», El País, 5 de diciembre de 2011.

https://elpais.com/diario/2011/12/05/cultura/1323039602_850215.html

27 «Palos de ciego», Diario Vasco, 8 de diciembre de 2011.

https://www.diariovasco.com/v/20111208/opinion/articulos-opinion/palos-ciego-20111208. html

28 Utilizamos aquí conscientemente el recurso de la dualidad léxica, tan habitual en Patria. 
euskera cobran 400 euros por dar una conferencia en una ikastola ${ }^{29}$. El tema de las charlas en ikastolas es un lugar común en Aramburu: incluso lo introdujo en Patria a través del personaje de Gorka.

Me han invitado a una ronda de lecturas por distintas ikastolas. Pagan bien, incluso muy bien. Contribuyo a la difusión del euskera» (p. 253).

Así pues, Gorka le sirve a Aramburu como correa de transmisión de sus ideas sobre la cultura vasca en general (educación incluida) y la literatura euskérica en particular. Ese mismo comentario de Gorka es incluido por Zaldua (2017) en la lista de inverosimilitudes e imprecisiones de la novela que él se ocupa de desmontar.

El programa Idazleak ikastetxeetan, que organiza visitas de escritores a la red educativa vasca (pública y concertada, no sólo a las ikastolas), no comenzó, en una versión incipiente y reducida, hasta el curso 1990-91, y el convenio que, para generalizarlo, acordaron el Gobierno Vasco y la Asociación de Escritores en lengua vasca no se firmó hasta 1996: es decir, de ningún modo en la segunda mitad de los ochenta (antes del asesinato del Txato), como sugiere el autor por boca de Gorka (pg. 253).

La incursión de Gorka desde muy joven en la literatura euskérica da pie a Aramburu para referirse a la misma:

a) Gorka, con dieciocho años, gana el premio literario de la Caja de Ahorros Provincial de Guipúzcoa con el poema Mendiko ahotsa ( «La voz del monte»), p. 345. Se convierte en un héroe en su pueblo, si bien su hermana Arantxa da por seguro que ningún convecino ha leído el poema (p. 347), baño de realidad que Gorka corrobora. Además, Gorka no se deja cegar por los halagos («Todo esto es un poco exagerado. Yo sólo he escrito un poema», p. 347; «Estaba harto de su propio poema, que, releído a solas en su habitación, le pareció de pronto tan flojo que no lo podía mirar sin vergüienza», p. 349).

b) Un hecho narrativo que sorprende es que, cuando Gorka entra a trabajar en la emisora de Bilbao, empieza a hacer un programa sobre literatura euskérica de media hora de duración «todos los días a las diez de la noche, salvo los sábados y domingos» (p. 360). ¿Un programa diario sobre literatura vasca, de lunes a viernes, en una emisora de Bilbao, ciudad con un número no desdeñable de vascohablantes pero con un número mucho mayor de no vascohablantes y con escasísima presencia del euskera en sus calles, en sus bares, en sus tiendas, etc.? Estamos ante otro elemento de inverosimilitud que Aramburu, consciente o inconscientemente, introduce en su obra.

${ }^{29}$ El escritor Juan Luis Zabala, que se encontraba entre el público, replicó en el turno de palabra final que la cantidad real no llegaba a la mitad de la citada por Aramburu. 
c) A través de Gorka, el lector accede también a otros puntos de vista de personajes de la novela sobre la literatura vasca. Por ejemplo, al de don Serapio (pp. 347-348), que convoca al muchacho para felicitarle por su premio literario. Le espeta un discurso de los suyos, del calibre del que le había lanzado anteriormente a Miren sobre Joxe Mari.

El euskera, alma de los vascos, necesita apoyarse en una literatura propia. Novelas, teatro, poesía. Todo eso. No basta que los niños vayan a la ikastola, que los padres les hablen y canten en euskera. Son más necesarios que nunca unos grandes escritores que lleven el idioma a su máximo esplendor. Un Shakespeare, un Cervantes, en euskera, eso sí que sería maravilloso. ¿Te imaginas? (p. 348).

El desarrollo de la literatura vasca, lograr homologarla con otras literaturas, no es para Don Serapio un fin en sí mismo, sino un mero instrumento para otros objetivos, extraliterarios, políticos.

Y (Gorka) se acordó, cómo no se iba a acordar, de lo que le había dicho recientemente Arantxa por teléfono. Tampoco el cura había mostrado interés por conocer su poema (p. 349).

d) En los consejos que Arantxa da a su hermano Gorka respecto a su futuro como escritor encontramos la visión crítica de Arámburu respecto a la literatura en euskera.

El euskera se convirtió en su principal fuente de ingresos ¿Lucrativa? De momento, para ir tirando. Hacía de todo (...). Arantxa (...) lo animó a dedicar en el futuro sus mayores esfuerzos creativos a la literatura infantil.

-Mientras escribas para niños, te dejarán tranquilo. Pero hay de ti, chaval, como te metas en líos de la tierra. En todo caso, si te da por escribir para mayores, pon tus historias lejos de Euskadi. En África o América, como hacen otros (p. 359).

\section{VII.- EL EUSKERA Y LA SANIDAD}

Como es sabido, el euskera es, junto al castellano, lengua cooficial de la CAV, tal como reza el Título Preliminar del Estatuto de Autonomía, aprobado por referéndum en 1979. A partir de dicha cooficialidad, en 1982 entró en vigor la Ley 10/1982, de 24 de noviembre, Básica de normalización del uso del Euskera, que, en su Título Segundo, reconoce «a todos los ciudadanos el derecho a usar tanto el euskera como el castellano en sus relaciones con la Administración Pública en el ámbito territorial de la Comunidad Autónoma, y a ser atendidos en la lengua oficial que elijan». Ese marco legal obliga, con mayor o menor grado de prescriptividad, a los ciudadanos que quieran trabajar en la Administración de la CAV a acreditar un cierto perfil lingüístico de euskera. El mayor grado de prescriptividad se da en el ámbito de la enseñanza. Donde algunos 
partidos políticos y medios de comunicación contrarios a dicha prescriptividad han hecho más hincapié ha sido en el ámbito de la sanidad, con un argumento muy reiterado, y formulado siempre a modo de pregunta: «iqué prefiere $\mathrm{Vd}$, que el médico le cure o que le atienda en euskera?» o «¿qué prefiere $\mathrm{Vd}$., un médico que no sepa euskera y que le cure, o un médico que sepa euskera y no le cure?». Pues bien, ese discurso lo encontramos en Patria, deslizado muy sutilmente por Aramburu al referirse a la fisioterapeuta que está tratando a Arantxa después de que esta sufriera el ictus.

La fisioterapeuta le da ánimos. Es muy maja. Habla muy poco euskera, casi nada, pero en este caso no importa» (p. 28).

En este breve pasaje observamos la estrategia estilística de Aramburu, reiterada durante toda la obra, de mezclar en un mismo pasaje su propia voz (la del narrador) y la de los personajes. «La fisioterapeuta le da ánimos» es la voz de Aramburu, el narrador. «Es muy maja. Habla muy poco euskera, casi nada, pero en este caso no importa» responde a otra voz. No es difícil averiguar a cuál: a la de Miren, por múltiples comentarios que pone Aramburu en su boca durante toda la novela. Y «en este caso no importa» significa que con la salud no se juega y que el euskera sí importa, pero en cuestiones menos trascendentes.

\section{VIII.- VASQUISMOS Y LETRA CURSIVA}

Aramburu hace un uso incorrecto de la letra cursiva en vasquismos que ya han sido aceptados por el DLE (Diccionario de la Lengua Española) y que, por tanto, no tendrían que figurar en cursiva: abertzale ${ }^{30}$, aurresku, batzoki, ertzaina, Ertzaintza, ikastola, ikurriña, lehendakari ${ }^{31}$, txangurro ${ }^{32}$, etc.

Asimismo, y dicho sea de paso, aparecen en cursiva préstamos de otras lenguas que también figuran en el DLE y que, por tanto, tampoco tendrían que aparecer en cursiva: souvenir (galicismo), pub (anglicismo).

En cambio, Aramburu no utiliza la cursiva en la palabra gora $(«$ Se lanzaron goras a ETA», p. 228) ${ }^{33}$, ni en la palabra Iparralde (pp. 248, 274), incluida, sin embargo, en el glosario. Ambas tendrían que figurar en cursiva al no estar recogidas en el DLE.

Por el contrario, Aramburu sí hace un uso correcto de la letra cursiva cuando emplea palabras vascas del espacuence que no han llegado al español y no

30 No obstante, el DLE, a día de hoy, prefiere para el español la forma aberzale, sin la consonante dental sorda que sí encontramos en la palabra en euskera.

31 Así lo escribe Aramburu, conforme al euskera batúa, aunque el DLE opta por la forma lendakari.

32 El DLE opta por la grafía castellana (changurro).

33 En su paso del euskera al español, gora ha sufrido un interesante proceso de recategorización: en español se utiliza como sustantivo, valor del que carece en euskera. 
están recogidas en el DLE (barkatu «perdona», тихи «beso», etc.), a veces con flexión castellana («muxus»). La palabra en espacuence presenta el género que tiene el equivalente castellano (en euskera no hay género, o casi no lo hay), v.gr. «un muxu grande» (p. 68), «una ekintza rápida y fácil» (p. 279).

Aramburu hace un uso plurifuncional de la letra cursiva. No la limita al espacuence, sino que también la emplea en rasgos lingüísticos del español coloquial (no solo el hablado en el País Vasco), tales como el uso del infinitivo con valor imperativo. También recurre a ella en los errores que comete en español el personaje alemán Klaus-Dieter («¿Vienes tú a mí visitar?», p. 323), así como en las frases en inglés ya citadas.

Hablando de errores, no queremos pasar por alto algo que nos ha llamado poderosamente la atención: el hecho de que una obra tan reconocida y premiada como Patria, con tantísimas reediciones y publicada por una editorial de referencia como Tusquets, adolezca de tantos errores de puntuación ${ }^{34}$ : la falta de comas, el uso de la coma o del punto en lugar de los dos puntos, etc.

\section{IX.- GLOSARIO FINAL}

Como indicábamos en el apartado II, tras el desenlace de la novela Aramburu incluye un glosario (pp. 643-646), con el siguiente encabezamiento entre paréntesis: «El presente glosario reúne vocablos y modismos procedentes del euskera usados en la novela. Tan sólo pretende servir de ayuda a los lectores poco o nada familiarizados con la lengua vasca». También había incluido un glosario en Los peces de la amargura (pp. 241-242), con un encabezamiento más preciso que en Patria: «Con frecuencia, en los relatos que integran el presente volumen figuran vocablos que muchos ciudadanos del País Vasco acostumbran emplear cuando se expresan en castellano. El glosario que sigue a continuación pretende servir de ayuda a los lectores poco o nada familiarizados con la lengua vasca».

Muchas de las expresiones del glosario de Patria corresponden al espacuence. En él, con buen criterio, no figura la palabra «euskera» ${ }^{35}$, que, en cambio, si había aparecido en el de Los peces de la amargura: «euskera (o euskara): vascuence». Es sorprendente, por innecesaria, esta glosa, dado que «euskera» es una palabra que se emplea en el castellano del resto de España, en los medios de comunicación, etc. desde hace bastantes años, figura en el DLE y cualquier castellanohablante sabe lo que significa. De hecho, se usa hoy en día

${ }^{34}$ He aquí una pequeña muestra de ellos: «Lo dicho, pan comido» (p. 280); «De otro modo no me explico cómo han venido tan pronto», p. 371; «Te aviso. Estos dos vienen en plan de mirar si tienes todo limpio», p. 409; «(...) y un contorno de Euskal Herria alrededor del lema: Gora Euskadi askatuta», p. 510; «Hazme un favor. Aunque te lleve la contraria, no discutas con ella», p. 607; «Poned por favor dos esquelas en El Diario Vasco, una en castellano y otra en euskera», p. 611 .

35 Aunque sí la escribe con letra cursiva en la página 438. 
en castellano mucho más que «vasco», y muchísimo más que «vascuence», que es la glosa aclaratoria de Aramburu.

En el glosario de Patria hay errores o imprecisiones que pasamos a corregir o matizar ${ }^{36}$ :

- aita: (pronunciación aguda: aitá) padre. ${ }^{37}$

Matización: esa pronunciación aguda (dato que, dicho sea de paso, no parece muy relevante para el lector de la novela) corresponde al dialecto guipuzcoano. En cambio, en vizcaíno es una palabra llana.

- ama: (pronunciación aguda: amá) madre. ${ }^{38}$

Matización: esa pronunciación aguda corresponde al dialecto guipuzcoano. En cambio, en vizcaíno es una palabra llana.

- arruntak: Nombre que los presos de ETA suelen asignar a los presos comunes.

Matización: la palabra vasca arrunt significa «común».

- barkatu: (infinitivo) perdonar (e imperativo) perdona, perdone.

Corrección: en euskera no hay infinitivos. Barkatu es un participio que significa «perdonado/a». -Tu es un sufijo participial vasco que, dicho sea de paso, procede del sufijo de participio pasado del latín. Con valor imperativo, el participio no solo puede referirse a la segunda persona del singular, sino también a la del plural.

- bietan jarrai: seguir en las dos (vías). Una, la fuerza militar, simbolizada por el hacha; otra, la inteligencia y astucia política, simbolizada por la serpiente.

Matización: convendría añadir un dato importante, a saber, que era el lema de ETA.

- cipayo: sobrenombre despectivo aplicado a los agentes de la Ertzaintza.

Corrección: sorprende sobremanera que se incluya esta palabra en un glosario de «vocablos o modismos procedentes del euskera», ya que el glosador (ya sea el propio Aramburu, ya sea otra persona de identidad no revelada) incurre aquí en un error de grueso calibre, ya que «cipayo» no es un vasquismo. En efecto, cipayo era el nombre que recibían los indios reclutados como soldados al servicio del Imperio Británico, Francia y Portugal durante el periodo colonial. El DLE recoge un segundo significado, con valor despectivo:

\footnotetext{
${ }^{36}$ Reproducimos textualmente la glosa del libro y, a continuación, añadimos la corrección o matización.

${ }^{37}$ En Los peces de la amargura y Años lentos, Aramburu escribe esta palabra sin cursiva y con tilde.

38 En Años lentos, Aramburu escribe esta palabra sin cursiva y con tilde.
} 
«secuaz a sueldo». Por extensión, en el País Vasco hubo quienes aplicaron esa denominación, con el citado sentido despectivo, a los miembros de la Ertzaintza por colaborar con la Policía Nacional y la Guardia Civil en la lucha contra ETA.

- Eusko gudariak (soldados vascos), título de una canción popular adoptada como himno por la izquierda abertzale.

Matización: la melodía, en efecto, procede de una canción popular (Atzo Bilbon nengoen «Ayer estaba en Bilbao»), pero es preciso añadir que a dicha melodía durante la Guerra Civil se le añadió otra letra en la cual la palabra gudari remitía a los soldados del cuerpo del ejército (republicano) Euzko Gudarostea creado por el Gobierno Vasco de entonces. Esa misma melodía, con esa misma letra de la Guerra Civil, fue adoptada por los sectores afines a ETA con el fin de establecer un paralelismo entre los soldados nacionalistas vascos de la Guerra Civil y los miembros de ETA. En cualquier caso, en Los peces de la amargura, la glosa de la misma expresión (Eusko gudariak) supone un desatino aún mayor: «soldados vascos, título del himno oficial del País Vasco». Nada más lejos de la realidad: el himno oficial de la CAV es la melodía Eusko Abendaren Ereserkia («Himno de la Raza Vasca»).

- gudari: combatiente, soldado, específicamente por la causa vasca.

Matización: Tal como hemos indicado respecto en la glosa anterior, gudari, en su origen, era cualquier soldado del Euzko Gudaroste. Décadas después, los sectores afines a ETA aplicaron dicho nombre a los miembros de la banda armada, al considerarlos continuadores de la misión militar de los gudaris de la Guerra Civil: luchar contra España. Nada más alejado de la realidad en el caso de los gudaris.

- ikastola: escuela.

Corrección: escuela cuya lengua vehicular es el euskera.

La definición de ikastola que aparece en el glosario de Los peces de la amargura («escuela en que se imparte la enseñanza predominantemente en vascuence») es mucho más atinada que la del glosario de Patria.

- izarren hautsa: el polvo de las estrellas. Canción con letra de Xabier Lete y música de Mikel Laboa.

Corrección: Izarren hautsa: polvo de estrellas. Canción con letra y música de Xabier Lete.

Matización: fue versionada por, entre otros, Mikel Laboa, Mikel Urdangarin, el grupo Ken Zazpi, etc.

- kontuz: cuidado, atención. 
Corrección: ¡cuidado! ¡atención! ${ }^{39}$

- maitia: (pronunciación con hiato: maitía) cariño, amor mío.

Matización: se suele usar (en la novela siempre es así) como vocativo.

- Topo: nombre popular del tren de vía estrecha que une San Sebastián con Hendaya.

Corrección: este vocablo no debería figurar en el glosario ya que no es palabra vasca.

- txapeo: situación del preso que se niega a salir al patio de la cárcel y permanece la jornada entera sin abandonar la celda.

Corrección: esa palabra no debería aparecer en el glosario al no ser de origen vasco. Se trata de un vocablo no recogido en el DLE perteneciente al argot carcelario. Creemos que puede proceder del verbo castellano «chapar» (en el sentido coloquial de «cerrar»).

- txoko: rincón.

Matización: También recibe este nombre el lugar donde celebran sus comidas las sociedades gastronómicas. De hecho, en Guipúzcoa al txoko se le llama «sociedad».

- TXORIA TXORI - EL PÁJARO

Corrección: TXORIA TXORI - EL PÁJARO ES PÁJARO

- Zutabe: nombre del boletín interno de ETA.

Matización: Zutabe: columna. Nombre del boletín interno de ETA.

\section{X.- CONCLUSIONES}

Patria es una novela de tesis o, sí se prefiere, una novela ideológica. Y, dentro de esa concepción, y aunque esté escrita en español, la lengua vasca, tanto por su presencia como por su ausencia, ocupa un lugar relevante. La mayoría de los personajes son vascohablantes y viven en una de las zonas más vascófonas del País Vasco, pero Aramburu los presenta hablando en espacuence (Cid Abasolo 2013), una suerte de pidgin consistente en castellano con un número reducido de expresiones vascas, utilizado en el País Vasco de forma general, incluso por los no vascohablantes. Hay, pues, una falta de verosimilitud lingüística en la novela que puede desconcertar al lector (no solamente al vascohablante), al cual le surge una duda en muchos diálogos: aunque estén escritos en castellano, los personajes, en realidad, ¿se están expresando en español o en euskera? La duda quizá no les surja a otros lectores. No repararán en

39 Sin los signos de admiración, esas palabras adquieren otro significado. 
ello. E, incluso, puede que agradezcan el gesto de Aramburu de, como él mismo dice, «dosificar el uso del euskera».

En Patria se invisibiliza el euskera en los diálogos (como lengua de los mismos), pero no en las pancartas, las pintadas, los eslóganes proferidos en manifestaciones (en ese ámbito, Aramburu no dosifica) y numerosas menciones a la lengua vasca, lo cual crea o puede alimentar en el lector una opinión negativa respecto a esta.

El euskera es un tema recurrente en Fernando Aramburu: en esta y otras obras suyas, y en sus declaraciones a la prensa. Incluso cuando lo invisibiliza, lo está visibilizando. Y cuando lo visibiliza, no lo hace para ajustarse a algo tan de agradecer en la narrativa (nos referimos a la narrativa que pretende ser realista) como la verosimilitud, sino con otros fines. Una actitud al servicio de una concepción de la literatura como forma de posicionamiento ideológico.

\section{BIBLIOGRAFIA}

Aramburu, F. (2006) Los peces de la amargura, Barcelona, Tusquets.

Aramburu, F. (2011) «Carta a los escritores vascos», El País, 5 de diciembre de 2011. Disponible en línea: https://elpais.com/diario/2011/12/05/cultura/1323039602_850215.html (consulta: 11.02.2019)

Aramburu, F. (2012) Años lentos, Barcelona, Tusquets.

Aramburu, F. (2016) Patria, Barcelona, Tusquets (edición utilizada: 19a).

Aramburu, F. (2018) Patria, Actes Sud Editions (traducción al francés de Claude Bleton).

Aramburu, F. (2019) Homeland, Penguin Random House (traducción al inglés de Alfred Macadam).

Cid Abasolo, K. (2008) «Gramatika Atxagaren literatur bideetan (I)» («La gramática en los caminos literarios de Bernardo Atxaga»), Gramatika jaietan. Patxi Goenagaren omenez (ed. X. Artiagoitia \& J. A. Lakarra), Anejos del Anuario del Seminario Julio Urquijo, 51, 2008, 173-194 [http://www.ehu.eus/ ojs/index.php/ASJU/article/viewFile/9777/9209]

Cid Abasolo, K. (2009) «Antroponimia en la literatura vasca contemporánea: Anjel Lertxundi», Los nombres de persona en la sociedad y en la literatura de tres culturas (coord. Karlos Cid Abasolo), Ediciones Sílex, Madrid, 2009, 13-51.

Cid Abasolo, K. (2013) «Hibridismo linguíístico en la Vasconia peninsular: sustrato vasco en el español», Revista de lenguas y literaturas catalana, gallega y vasca, 18, UNED, 263-282. Disponible en línea: http://revistas.uned.es/ index.php/RLLCGV/article/view/10798

Cid Abasolo, K. (2014) «Hibridismo lingüístico en la Vasconia peninsular: influjo de la lengua castellana en la lengua vasca», Revista de lenguas y literaturas 
catalana, gallega y vasca, 19, UNED, 247-266. Disponible en línea: http:// revistas.uned.es/index.php/RLLCGV/article/view/13768/12454

Cid Abasolo, K. (2015) «Anjel Lertxundiren pertsonaien izenak / The names of the characters in Anjel Lertxundi's works», Anuario del Seminario de Filología Julio Urquijo, 49-1/2, San Sebastián, 2015 [2018], 229-254. http://www.ehu. eus/ojs/index.php/ASJU/article/view/18816/17765

Cid Abasolo, K. (2018) «Omen partikularen erabilera eta gaztelaniazko ordainak: Anjel Lertxundiren kasua / The use of the omen particle and its equivalents in Spanish: The case of Anjel Lertxundi», Studia Philologica et Diachronica in honorem Joakin Gorrotxategi, Anuario del Seminario de Filología Julio Urquijo, 52-1/2, San Sebastián, 153-173.

Lertxundi, A. (2011) «Palos de ciego», Diario Vasco, 8 de diciembre. Disponible en línea: https://www.diariovasco.com/v/20111208/opinion/articulos-opinion/palos-ciego-20111208.html (consulta: 11.12.2018).

Portela, E. (2016) El eco de los disparos, Barcelona, Galaxia Gutenberg.

Prados, L. (2011) «Los escritores vascos no son libres, están subvencionados» (entrevista a Fernando Aramburu), El País, 30 de noviembre. Disponible en línea: https://elpais.com/diario/2011/12/01/cultura/1322694002_850215. html (consulta: 20.11.2018).

Zaldua, I. (2012) Ese idioma raro y poderoso: Once decisiones cruciales que un escritor vasco está obligado a tomar, Madrid, Lengua de Trapo.

\section{Materiales de internet}

González-Vinuesa, L. (2017) Basque vs Spanish encounters in Aramburu's «Patria»: blurring or shifting cultural boundaries?, https://www.academia. edu/36017052/Basque_vs_Spanish_Encounters_in_Aramburus_Patria_blurring_or_shifting_cultural_boundaries_by_luz_gonz\%C3\%A1lez-vinuesa_2017.pdf (consulta: 23.01.2019).

Olaziregi, M.J. (2018) «A vueltas con la madre patria», Politika, 29 de junio, https://www.politika.io/fr/notice/a-vueltas-con-madre-patria (consulta: 24.01.2019).

Puente, L. (2017) «Cambios de código lingüístico en Patria de Fernando Aramburu», Books and Earl Grey, 10 de enero, https://booksandearlgreyblog. wordpress.com/2017/01/10/cambios-de-codigo-linguistico-en-patria-de-fernando-aramburu/ (consulta: 23.01.2019).

RAE, Diccionario de la Lengua Española (DLE): https://dle.rae.es

Sainz Borgo, K. (2016) «Fernando Aramburu: «Del País Vasco me llevé el dolor, la evocación y el deseo de intervenir con la palabra»», Zenda, 20 de septiembre, https://www.zendalibros.com/fernando-aramburu-del-paisvasco-me-lleve-dolor-la-evocacion-deseo-intervenir-la-palabra/ (consulta: 24.01.2019). 
Wikipedia, https://es.wikipedia.org

Zabala, J.L. (2016) «Saizarbitoriaren «zaska» Arambururi eta beste emozio batzuk», Berria, 4 de noviembre, https://www.berria.eus/blogariak/inonizatekotan/2016/11/04/saizarbitoriaren-zaska-arambururi-eta-beste-emoziobatzuk/ (consulta: 13.02.2019).

Zaldua, I. (2017) «La literatura, ¿sirve para algo? Una crítica de Patria, de Fernando Aramburu», Viento sur, 22 de marzo, https://vientosur.info/spip. php?article12381 (consulta: 20.11.2018).

Zallo, R. (2017) «Patria asesina versus patria colectiva. Sobre la novela Patria de Fernando Aramburu», Sinpermiso, 12 de marzo, http://www.sinpermiso. info/textos/patria-asesina-versus-patria-colectiva-sobre-la-novela-patria-defernando-aramburu (consulta: 8.01.2019).

\section{Películas}

Ocho apellidos vascos (2014), dirigida por Emilio Martínez Lázaro. 